SYLWIA PIEŃKOWSKA-KAMIENIECKA

PATRYCJA KOWALCZYK-RÓLCZYŃSKA

JOANNA RUTECKA-GÓRA

https://doi.org/10.33995/wu2021.4.6

\title{
Wpływ poziomu wiedzy o ubezpieczeniach społecznych na dodatkowe oszczędzanie na emeryturę w Polsce
}

W artykule przeanalizowano wpływ wiedzy osób indywidualnych o systemie ubezpieczeń społecznych, w tym o systemie emerytalnym, na skłonność do gromadzenia dodatkowych oszczędności emerytalnych. Skorzystano z danych pochodzacych z badania przeprowadzonego przez Zakład Ubezpieczeń Społecznych w 2016 roku na reprezentatywnej próbie 1030 Polaków. Stosujqc model regresji logistycznej i test niezależności chi-kwadrat, ustalono, że wraz z wyższym poziomem wiedzy o ubezpieczeniach społecznych zwiększa się również skłonność do oszczędzania. Ponadto, na poziom tej wiedzy wpływaja źródła informacji, z których jest ona nabywana. Najwyższq wiedzę o ubezpieczeniach społecznych maja osoby, które pozyskuja ja od rodziny i znajomych, z ZUS-u oraz z rozmów ze specjalistami. Uzyskane wyniki wydajq się istotne dla wszystkich instytucji rynku finansowego, które oferuja długoterminowe produkty oszczędnościowo-inwestycyjne, w szczególności dla zakładów ubezpieczeń na życie, których oferta w zakresie gromadzenia oszczędności na starość jest coraz bogatsza i które zatrudniaja specjalistów edukujacych potencjalnych ubezpieczonych.

Słowa kluczowe: wiedza ubezpieczeniowa, świadomość emerytalna, oszczędzanie na starość, dodatkowy system emerytalny, źródła wiedzy.

JEL: G51, G53, J26, J32 


\section{Wprowadzenie}

Niekorzystne zmiany demograficzne, jakie w ostatnich dziesięcioleciach zachodzą w rozwiniętych krajach świata, prowadzą do szybkiego starzenia się ludności ${ }^{1}$. Wskaźnik obciążenia systemu emerytalnego ludźmi starszymi (ang. old age dependency ratio), określony relacją osób w wieku poprodukcyjnym do osób w wieku produkcyjnym² oddziałuje na możliwości finansowania świadczeń wypłacanych obecnym (i przyszłym) emerytom z publicznych systemów emerytalnych. Sytuacja demograficzno-ekonomiczna w danym kraju wpływa z kolei na kierunki polityki społecznej w zakresie zabezpieczenia na starość, w tym na konieczność wprowadzania istotnych reform i korektę wysokości emerytur z bazowych systemów emerytalnych, oraz na stosunek obywateli do dodatkowego oszczędzania na emeryturę ${ }^{3}$. Przykład głębokiej reformy emerytalnej można obserwować w Polsce, która w 1999 roku wprowadziła wielofilarowy system oparty na formule zdefiniowanej składki i zawierający elementy finansowania kapitałowego ${ }^{4}$, z zapewnionym miejscem dla dodatkowego oszczędzania na emeryturę ${ }^{5}$. Jest to o tyle istotne, że w bazowym systemie o zdefiniowanej składce odpowiedzialność za kluczowe decyzje emerytalne przeniesiona została na indywidualnych uczestników. Decydują oni o podziale składki emerytalnej, okresie składkowania i momencie przejścia na emeryturę. Przy czym minimalny wiek emerytalny w Polsce, wcześniej stopniowo podwyższany do 67 lat dla kobiet i mężczyzn, w 2017 r. został ponowie obniżony do 60 lat dla kobiet i 65 lat dla mężczyzn ${ }^{6}$, co zwiększyło odpowiedzialność uczestników systemu za adekwatność ich emerytur z obowiązkowej części zabezpieczenia emerytalnego. Osoby indywidualne decyduja ponadto o rodzaju i zakresie dodatkowego oszczędzania oferowanego w wielu formach produktowych, w tym o uczestnictwie w planach wspieranych dopłatami państwa badź pracodawcy. Dobre wybory emerytalne wymagajajednak posiadania wiedzy o zasadach funkcjonowania systemu emerytalnego oraz odpowiednich kompetencji „emerytalnych”. Tylko wówczas indywidualni uczestnicy mogą, odpowiednio do własnych potrzeb, zabezpieczyć się na okres starości, świadomie planując moment przejścia na emeryturę oraz podejmując kluczowe decyzje

1. F. Chybalski, Pensionable age vs cross-country diversity of economic activity of the near-elderly, „Journal of Economics, Finance and Administrative Science" 2021, Vol. 26 Issue 51; A.M. Jaime-Castillo, Public opinion and the reform of the pension systems in Europe: the influence of solidarity principles, „Journal of European Social Policy" 2013, No. 23 (4), s. 390-405.

2. D.M. Adiev, W.C. Sanderson, S. Scherbov, The inverse relationship between life expectancy-induced changes in the old-age dependency ratio and the prospective old-age dependency ratio, "Theoretical Population Biology" 2019, No. 125, s. 1-10.

3. E. Marcinkiewicz, F. Chybalski, How to measure and compare pension expenditures in cross-country analyses? Some methodological remarks, „International Journal of Business and Management” 2014, Vol. II[4], s. 43-59.

4. Szerzej o kapitałowej części bazowego systemu emerytalnego w Polsce: B. Hadyniak, J. Monkiewicz, Fundusze emerytalne. II filar, Poltext, Warszawa 1999; Otwarte fundusze emerytalne w Polsce. Analiza działalności inwestycyjnej, finansów i decyzji członków, [red.] F. Chybalski, Wydawnictwo CH Beck, Warszawa 2009.

5. A. Chłoń, M. Góra, M. Rutkowski, Shaping Pension Reform in Poland: Security Through Diversity, „SP Discussion Paper" 1999, No. 9923,World Bank, Washington; M. Góra, System emerytalny, Polskie Wydawnictwo Ekonomiczne, Warszawa 2003; M. Góra, J. Rutecka, Elastyczny system emerytalny a obecne i przyszłe potrzeby jego uczestników, „Ekonomista” 2013, nr 6. http://hdl.handle.net/20.500.12182/932 [dostęp: 10.12.2021].

6. A. Chłoń-Domińczak, F. Chybalski, M. Rutkowski, The retirement age and the pension system, the labor market and the economy, „mBank-CASE Seminar Proceedings” 2021, No. 167, s. 32. 
w zakresie długości okresu dodatkowego oszczędzania czy wielkości gromadzonych w dodatkowych planach emerytalnych środków, w tym w formie ubezpieczeniowych funduszy kapitałowych. Wiedza ta jest również niezbędna, aby wybrać najbardziej odpowiednią ofertę spośród produktów emerytalnych oferowanych przez różne instytucje sektora finansowego, w tym zakłady ubezpieczeń na życie. Skuteczne dostarczenie wiedzy i budowanie kompetencji wymaga przy tym przekazania informacji najbardziej potrzebnych indywidualnym uczestnikom, w zrozumiały dla nich sposób? oraz przy użyciu właściwych kanałów komunikacji.

Celem artykułu jest identyfikacja kanałów pozyskiwania wiedzy o ubezpieczeniach społecznych wpływających na poziom wiedzy osób indywidualnych na temat zabezpieczenia społecznego. Ponadto w artykule zbadano, jak poziom i źródła wiedzy wpływają na oszczędzanie na emeryturę w Polsce.

W związku z powyższym celem w niniejszym opracowaniu sformułowano następujące hipotezy badawcze, które poddano weryfikacji statystycznej:

Hipoteza 1: Poziom wiedzy o ubezpieczeniach społecznych Polaków wpływa istotnie na skłonność do oszczędzania na starość.

Hipoteza 2: Osobami o wyższej wiedzy w obszarze ubezpieczeń społecznych są te, które ją pozyskują od rodziny, znajomych i pracowników Zakładu Ubezpieczeń Społecznych.

W artykule skorzystano $z$ danych pochodzących z reprezentatywnego badania ilościowego przeprowadzonego na zlecenie Zakładu Ubezpieczeń Społecznych ${ }^{8}$ przez Instytut Spraw Publicznych oraz Millward Brown w 2016 roku $(\mathrm{N}=1030)^{9}$. Do analizy danych zastosowano model regresji logistycznej oraz test niezależności chi-kwadrat.

\section{Dodatkowe oszczędzanie na emeryturę a wiedza na temat ubezpieczeń społecznych i kompetencje finansowe - przegląd literatury}

Od 1999 roku system zabezpieczenia emerytalnego w Polsce składa się z kilku warstw. Pierwszą stanowi obowiązkowy niefinansowy system o zdefiniowanej składce (nonfinancial defined contribution, NDC) ${ }^{10}$, zarządzany przez Zakład Ubezpieczeń Społecznych (ZUS). Druga finansowy system o zdefiniowanej składce (funded defined contribution, FDC), który tworzą otwarte fundusze emerytalne $[\mathrm{OFE}]^{11}$ wraz z zarządzającymi nimi powszechnymi towarzystwami emerytalnymi (PTE). Natomiast trzecią - dodatkowe plany emerytalne, funkcjonujące $w$ formie

7. J. Rutecka-Góra, K. Bielawska, M. Hadryan, P. Kowalczyk-Rólczyńska, S. Pieńkowska-Kamieniecka, Zrozumiałość, przejrzystość i efektywność indywidualnych produktów emerytalnych w Polsce, Oficyna Wydawnicza SGH, Warszawa 2020, https://doi.org/10.33119/978-83-8030-378-2.2020.202 [dostęp: 18.12.2021].

8. Autorki niniejszego opracowania składają podziękowanie Zakładowi Ubezpieczeń Społecznych za udostępnienie wyników z badań ilościowych.

9. Zob. Wiedza i postawy o ubezpieczeniach społecznych. Raport z badań, ZUS, Instytut Spraw Publicznych, Warszawa 2016, https://www.zus.pl/documents/10182/44573/Raport+wiedza+system+emerytalny/040b d2a1-094a-4d97-9d77-e0bddc19e845 [dostęp: 18.12.2021].

10. Szerzej: M. Góra, E. Palmer, NDC: The Generic Old-Age Pension Scheme, [w:] Progress and Challenges of Nonfinancial Defined Contribution Pension Schemes Volume 1: Addressing Marginalization, Polarization, and the Labor Market, [red.] R. Holzmann, E. Palmer, R. Palacios, S. Sacchi, World Bank, Washington 2019, doi: 10.1596/978-1-4648-1453-2 [dostęp: 18.12.2021].

11. Szerzej: F. Chybalski, op. cit. 
zarówno grupowej, jak i indywidualnej. Plany grupowe prowadzone sa jako pracownicze programy emerytalne (PPE), wprowadzone w 1999 roku, bądź pracownicze plany kapitałowe (PPK), wdrażane stopniowo od 2019 roku i wykorzystujące mechanizm automatycznego zapisu. Natomiast indywidualne plany emerytalne oferowane sa jako indywidualne konta emerytalne (IKE), funkcjonujące od 2004 roku, bądź indywidualne konta zabezpieczenia emerytalnego (IKZE), wprowadzone od 2012 roku. Wszystkie z wymienionych planów mogą być zarządzane przez różne instytucje finansowe i być oferowane w różnych formach produktowych.

Wielość form, instytucji i zasad funkcjonowania powoduje, że dodatkowy system emerytalny w Polsce jest obecnie bardzo skomplikowany. Może to powodować znaczne problemy z wyborem planu i produktu z punktu widzenia indywidualnych oszczędzających, a w konsekwencji także rezygnację z dodatkowego oszczędzania w ogóle. Problem dużego skomplikowania pogłębiany jest przez różne zasady finansowania składek, limity wpłat oraz odmienne zachęty i reżimy podatkowe stosowane w poszczególnych rodzajach planów ${ }^{12}$. Osoba indywidualna planująca dodatkowo oszczędzać na emeryturę musi zatem posiadać dużą wiedzę o funkcjonowaniu systemu emerytalnego i kompetencje finansowe, aby dokonać wyboru planu, który będzie najlepiej odpowiadał jej potrzebom.

Przeprowadzone przez Instytut Spraw Publicznych w 2016 roku badanie dotyczące wiedzy o ubezpieczeniach społecznych jednoznacznie wskazało, że zaledwie $7 \%$ Polaków taką wiedzę posiada ${ }^{13}$. Niepokojący jest fakt, iż ponad 46\% respondentów w ogóle nie szuka wiedzy w tym obszarze. Dominik Owczarek ${ }^{14}$ tłumaczy niejako tę sytuację, wskazując, że nabyciu i ugruntowaniu wiedzy o ubezpieczeniach społecznych nie sprzyjają dość częste we wcześniejszych latach zmiany, które sprawiają, że dla niektórych grup system zabezpieczenia społecznego staje się nieczytelny. Z kolei Robert Marczak ${ }^{15}$, analizując wyniki tego samego badania, podaje, że respondenci nie tylko nie posiadają wiedzy o ubezpieczeniach społecznych, ale także nie korzystają z dostępnych instrumentów dodatkowego zabezpieczenia, pokładając nadzieję w bazowym systemie emerytalnym, którego emanacjąjest jednak niezbyt dobrze oceniany przez nich ZUS. Również Sylwia Pieńkowska-Kamieniecka, Damian Walczak i Reinhold Schnabel ${ }^{16}$ podkreślają znaczenie wiedzy ubezpieczeniowej w obliczu postępującej finansjalizacji życia codziennego i wskazuja na jej niski poziom zwłaszcza wśród kobiet, osób słabiej wykształconych i mieszkających na wsi. Można jednocześnie przypuszczać, że niski poziom wiedzy o ubezpieczeniach społecznych implikuje niski poziom uczestnictwa w dobrowolnych formach gromadzenia oszczędności na starość, mając wpływ na adekwatność świadczeń z całego systemu emerytalnego.

Dinesh Rajan, Fadzli Aziz i Norida Manab ${ }^{17}$ stwierdzili, że wiedza uczestników o funkcjonowaniu ubezpieczeń społecznych zwiększa się po podjęciu akcji edukacyjnej przez instytucję zarządzająca

12. Szerzej: J. Rutecka-Góra i in., op. cit.

13. Wiedza i postawy o ubezpieczeniach społecznych ..., s. 27-28.

14. D. Owczarek, Niski poziom wiedzy a wyrazista postawa Polaków wobec ubezpieczeń społecznych i Zakładu Ubezpieczeń Społecznych, „Ubezpieczenia Społeczne. Teoria i Praktyka” 2017, nr 1, s. 153-170.

15. R. Marczak, Wiedza Polaków o systemie emerytalnym. Wyniki badań empirycznych, „Polityka Społeczna” 2016, nr 1, s. 28-37.

16. S. Pieńkowska-Kamieniecka, D. Walczak, R. Schnabel, Social insurance knowledge: implications for education, „Ubezpieczenia Społeczne. Teoria i Praktyka” 2021, nr 2 (149), s. 3-24. Autorzy w swoim opracowaniu przeprowadzili analizy na podstawie tej samej bazy danych, co autorki niniejszego opracowania.

17. D. Rajan, F. Aziz, N. Manab, Service Quality of Social Insurance Industry and Customer Satisfaction from Malaysian Perspective: Customer Knowledge as a Moderator, "International Academic Research Journal of Business and Technology" 2018, No. 4[1], s. 1-?. 
Wpływ poziomu wiedzy o ubezpieczeniach społecznych na dodatkowe oszczędzanie...

publicznym systemem emerytalnym, w szczególności w zakresie rozumienia polityki społecznej oraz samych zasad regulujących funkcjonowanie systemu, przy czym przekazywana informacja powinna zawierać nie tylko generalne zasady, ale przede wszystkim informacje o wprowadzonych korektach i aktualizacjach, gdyż osoby indywidualne są bardziej skłonne do reakcji w odpowiedzi na wprowadzane zmiany. Wpływ wiedzy o zasadach funkcjonowania systemu emerytalnego na deklarowany wiek przejścia na emeryturę potwierdziły także Sonia Buchholtz oraz Joanna Rutecka-Góra ${ }^{18}$, podkreślając ponadto skuteczność efektu kadrowania i odpowiednio przygotowanej informacji emerytalnej.

Szeroko rozumiane kompetencje w zakresie zabezpieczenia emerytalnego obejmują zarówno posiadanie wiedzy finansowej w aspekcie gromadzenia oszczędności na starość, jak i wiedzę o funkcjonowaniu systemu ubezpieczeń społecznych. Zbyt późne podjęcie decyzji o rozpoczęciu oszczędzania na starość może doprowadzić do zgromadzenia zbyt niskiego kapitału, a tym samym do nieosiągnięcia założonego celu ${ }^{19}$. Świadomość niskiej stopy zastapienia w przyszłości powinna zwiększać skłonność do dodatkowych oszczędności emerytalnych. Jednak podejmowanie optymalnych decyzji dotyczących standardu życia po przejściu na emeryturę wymaga posiadania przez jednostki konkretnej wiedzy na temat systemu emerytalnego i znajomości zasad jego funkcjonowania ${ }^{20}$.

Niska skłonność do oszczędzania wynika z braku lub niedostatku wiedzy o oszczędzaniu emerytalnym oraz braku informacji, gdzie i jak szukać odpowiedniego doradcy w tym zakresie, a także: czy w ogóle warto oszczędzać ${ }^{21}$. Alan Gustman i Thomas Steinmeier ${ }^{22}$ mówia ponadto wprost, że brak informacji o świadczeniach emerytalnych jest obecnie normą. Niedoskonałości polityki informacyjnej dotykaja przy tym zarówno obowiązkowego systemu emerytalnego, jak i systemu dodatkowego, co jest wyraźnie podkreślane w cyklicznych raportach Better Finance ${ }^{23}$.

18. S. Buchholtz, J. Rutecka-Góra, The Impact of Framing and Anchoring on Postponing Labour Market Exit Evidence from Polish NDC+FDC Pension Scheme, "European Research Studies Journal" 2021, Vol. XXIV, Issue 2, s. 122-138, http://doi.org/10.35808/ersj/2116 [dostęp: 18.12.2021].

19. R. Clark, M. d'Ambrosio, Saving for Retirement: The Role of Financial Education, "TIAA-CREF Institute Working Paper 4-070102-A" 2002.

20. H.M. Prast, A.H.O. van Soest, Financial Literacy and Preparation for Retirement, "Intereconomics” 2016, No. 51(3), s. 113-118. A. Lusardi, P. Michaud i 0. Mitchell wykazali, że działania podejmowane w celu zwiększenia wiedzy finansowej mogą wpływać na zdolność ludzi do oszczędzania i inwestowania. Wykazali oni, że zróżnicowanie wiedzy finansowej odpowiada za 30-40\% nierówności w zgromadzonym przez Amerykanów majątku emerytalnym. Co więcej, dowodzą, że kompetencje finansowe odgrywają kluczową rolę w gromadzeniu oszczędności i budowaniu majątku i dochodzą do wniosku, że przeprowadzenie reformy ograniczajacej świadczenia z ubezpieczeń społecznych prowadzi do poszerzenia wiedzy finansowej. A. Lusardi, P.-C. Michaud, O.S. Mitchell, Optimal Financial Knowledge and Wealth Inequality, „Journal of Political Economy” 201?, No. 125(2), s. 431-47?.

21. L. Foster, Young People and Attitudes towards Pension Planning, „Social Policy \& Society” 2017, No. 16[1], $65-80$.

22. A.L. Gustman, T.L. Steinmeier, Imperfect Knowledge, Retirement and Saving, "NBER Working Paper" $2001 \mathrm{Nr}$ 8406, https://www.nber.org/system/files/working_papers/w8406/w8406.pdf [dostęp: 18.12.2021].

23. A. Mączyńska, J. Šebo, S.D. Voicu, E. Carlucci, L. Christoff, L. Christensen, M. Deinema, J. Hagen, J.A. Herce, A. Houdmont, L. Gabaut, Y. Popova, L. Grænge-Hansen, M. Meštan, G. Naacke, D. Nacheva, C. Nava, M. Joab, G. Prache, J. Rutecka-Góra, T. Url, Long-Term and Pension Savings. The Real Return. 2020 Edition, Better Finance, Brussels 2020. 
Z drugiej strony, analizy przeprowadzone przez Anne Nolan i Karinę Doorley ${ }^{24}$ na rynku irlandzkim wskazały, że osoby z wyższym poziomem wiedzy finansowej oczekują znacznie wyższych dochodów na emeryturze.

Liczne badania ${ }^{25}$ potwierdzają, że poziom zamożności gospodarstw domowych i kompetencje w zakresie zarządzania majątkiem zależą od wiedzy i umiejętności nabytych podczas edukacji szkolnej, również na poziomie podstawowym. Źródłem wiedzy finansowej jest także rodzina (szczególnie rodzice), przyjaciele i media, w tym telewizja, radio, gazety i książki oraz Internet ${ }^{26}$. W przypadku nabywania produktów ubezpieczeniowych, w tym ubezpieczeń na życie uzupełniających świadczenia z publicznego systemu ubezpieczeń społecznych, istotną i coraz częściej wykorzystywana platforma wiedzy jest Internet ${ }^{2 ?}$.

Niewystarczający poziom wiedzy i kompetencji finansowych osób indywidualnych jest zjawiskiem powszechnym na całym świecie ${ }^{28}$. W Polsce wiedza finansowa obywateli jest regularnie badana przez kilka instytucji, m.in.: Fundację Kronenberga, Narodowy Bank Polski, Grupę ING, OECD oraz Związek Banków Polskich. Raporty wszystkich wymienionych instytucji informuja, że poziom wiedzy finansowej Polaków jest raczej niski, nie myślą oni w długim horyzoncie czasowym i preferuja bieżącą konsumpcję. Narodowy Bank Polski ustalił²9, że głównymi faktorami wiedzy ekonomicznej sa: wykształcenie, wiek, aktywność zawodowa, korzystanie z produktów finansowych, używanie nowych technologii (Internetu, smartfonu), regularne czytanie prasy codziennej i czasopism oraz wcześniejsze doświadczenia edukacyjne w obszarze finansów (w domu, szkole i poza nią). Badania $0 E C D^{30}$ pokazują natomiast, że co drugiemu Polakowi brakuje wiedzy finansowej, co ma negatywny wpływ na postawy i zachowania finansowe. Ponadto Polacy charakteryzuja się wyższą subiektywną niż obiektywną wiedzạ finansową, co może utrudniać edukację finansową i może sprzyjać niepożądanym zjawiskom, takim jak misseling ${ }^{31}$. Mając niską wiedzę i świadomość emerytalna, Polacy oczekuja jednocześnie wysokich stóp zwrotu i związanych z nimi gwarancji w planach dodatkowego oszczędzania. ${ }^{32}$ Mała wiedza i niska skłonność do oszczędzania znajduja

24. A. Nolan, K. Doorley, Financial Literacy and Preparation for Retirement, "IZA DP” 2019, No. 12187.

25. Zob. m.in. J.R. Behrman, O.S. Mitchell, C. Soo, D. Bravo, Financial Literacy, Schooling, and Wealth Accumulation, „NBER Working Paper” 2010, No. 16452; N.A. Yunikawati, M.P. Priambodo, E.Y. Puspasari, N. Istiqomah, Is it Important for Elementary School Students to Learn the Basics of Finance?, „International Research Conference on Economics and Business. KnE Social Sciences" 2021.

26. Y. Mimura, J. Koonce, S.W. Plunkett, L. Pleskus, Financial Information Source, Knowledge, and Practices of College Students from Diverse Backgrounds, "Journal of Financial Counseling and Planning" 2015, No 26 (1); C.F. Bowen, Financial Knowledge Of Teens And Their Parents, „Financial Counseling and Planning” 2002, No. 13(2).

27. Z. Liu, W. Li, T. Zhang, Internet and private insurance participation, „International Journal of Finance \& Economics" 28.08.2020.

28. A. Lusardi, O.S. Mitchell, Financial Literacy and Retirement Preparedness: Evidence and Implications for Financial Education Programs, „Wharton Pension Research Council Working Papers” 2007, No. 568.

29. Szerzej: Prezentacja wyników „Badania świadomości i wiedzy ekonomicznej Polaków”, NBP, 2020, https:// www.nbp.pl/edukacja/badania/wiedza-ekonomiczna-polakow.pdf [dostęp: 12.07.2021].

30. OECD/INFE International Survey of Adult Financial Literacy Competencies, OECD, Paris 2016, www.oecd.org/ finance/OECD-INFE-International-Survey-of-Adult-Financial-Literacy-Competencies.pdf [dostęp: 15.07.2021].

31. Ibidem.

32. E. Cichowicz, J. Rutecka-Góra, Świadomość Polaków dotyczqca dodatkowego oszczędzania na starość - próba oceny oraz identyfikacji niezbędnych działań, „Problemy Polityki Społecznej. Studia i Dyskusje” 2017, nr 3, https://doi.org/10.33119/PPSSID.2017.38.3 [dostęp: 18.12.2021]. 
także potwierdzenie w badaniach CBOS, Izby Zarządzających Funduszami i Aktywami ${ }^{33}$, TNS Polska czy ZUS, z których wynika, że większość Polaków nie oszczędza na emeryturę i nie zna instrumentów finansowych służących temu celowi. Szczególnym problemem jest niska świadomość emerytalna Polaków i brak internalizacji zasad funkcjonowania systemu emerytalnego o zdefiniowanej składce dokładnie przeanalizowana przez Janusza Czapińskiego i Marka Górę ${ }^{34}$. Inne publikacje ${ }^{35}$ wskazuja przy tym, że 64\% Polaków nie jest zadowolona z otrzymanej edukacji szkolnej w obszarze finansów, podczas gdy niemal wszyscy (92\%) uważają, że wiedza finansowa jest bardzo przydatna w codziennym życiu ${ }^{36}$.

\section{Metody badawcze i charakterystyka zmiennych}

Analizy przedstawione w niniejszym artykule wykorzystują dane z reprezentatywnego dla ogółu ludności Polski badania ilościowego ${ }^{37}$ przeprowadzonego na zlecenie Zakładu Ubezpieczeń Społecznych przez Instytut Spraw Publicznych we współpracy z Millward Brown przy wykorzystaniu techniki CAPI (wywiad osobisty wspomagany komputerowo) na przełomie lipca i sierpnia 2016 roku. Było ono częścią większego badania, tzw. „omnibusa”. Próba badawcza składała się z 1030 osób w wieku 15-75 lat. Miała ona charakter kwotowo-losowy i była dobierana z bazy adresowej GUS. Warstwowanie uwzględniało wielkość miejscowości oraz rozmieszczenie terytorialne w ramach województw, a także płeć i wiek dobieranych osób metodą „random route”.

Zważywszy na postawiony w artykule cel, posłużono się modelem regresji logistycznej, aby zbadać, jakie analizowane zmienne społeczno-demograficzne mają wpływ na oszczędzanie na starość oraz jakie jest znaczenie wiedzy i źródeł informacji o ubezpieczeniach społecznych w gromadzeniu kapitału na okres po zaprzestaniu aktywności zawodowej. Za zmienną zależna (objaśniana) przyjęto zmienną dychotomiczną Y. W przypadku, gdy dany respondent oszczędza dodatkowo na starość, taka zmienna przyjmuje wartość 1, natomiast gdy respondent nie gromadzi oszczędności na starość, zmienna ta przyjmuje wartość 0.

Jak wskazuje literatura przedmiotu, model regresji logistycznej dla zmiennej dychotomicznej opisany jest równaniem ${ }^{38}$ :

$$
P\left(Y=1 \mid X_{1}, X_{2}, \ldots, X_{k}\right)=\frac{e^{\beta_{0}+\sum_{i=1}^{k} \beta_{i} \times X_{i}}}{1+e^{\beta_{0}+\sum_{i=1}^{k} \beta_{i} \times X_{i}}}
$$

33. Międzypokoleniowe rozmowy o długach, raport dla Grupy KRUK, TNS Polska, Warszawa 2016.

34. J. Czapiński, M. Góra, Świadomość „emerytalna” Polaków. Raport z badania ilościowego, Publikacje Europejskiego Kongresu Finansowego, Warszawa 2016.

35. B. Świecka, A. Grzesiuk, D. Korczak, O. Wyszkowska-Kaniewska, Financial literacy and financial education. Theory and Survey, De Guyter Oldenbourg, Berlin 2019.

36. Międzypokoleniowe rozmowy ..., op. cit.; B. Świecka, A. Grzesiuk, D. Korczak, 0. Wyszkowska-Kaniewska, op. cit.

37. Drugą część badania stanowiło przeprowadzone równolegle badanie jakościowe przy wykorzystaniu techniki zogniskowanego wywiadu grupowego, jednakże nie było ono podstawą przygotowania niniejszego opracowania. Zob. Wiedza i postawy o ubezpieczeniach społecznych. Raport z badań, ZUS, Instytut Spraw Publicznych, Warszawa 2016, https://www.zus.pl/documents/10182/44573/Raport+wiedza+system+emerytalny/040b d2a1-094a-4d97-9d77-e0bddc19e845, s. 3-4 [dostęp: 18.12.2021].

38. A. Stanisz, Modele regresji logistycznej. Zastosowanie w medycynie, naukach przyrodniczych i społecznych, StatSoft Polska, Kraków 2016, s. 166. 
gdzie: $\beta_{i} i=0, \ldots, k$ są współczynnikami regresji, $X_{1}, X_{2}, \ldots, X_{k}-$ zmienne niezależne (mierzalne lub jakościowe).

Do interpretacji wskazanego modelu regresji logistycznej można wykorzystać iloraz szans (odds ratio ${ }^{39}$ :

$$
O R=e^{\beta i}
$$

$O R$ pokazuje, o jaką krotność zmieni się iloraz szans na to, że $Y=1$ do szansy na to, że $Y=0$ dla jednostkowego wzrostu zmiennej $X_{i}$ (ceteris paribus) ${ }^{40}$ :

$O R>1$ oznacza wzrost ilorazu szans,

$O R<1$ oznacza spadek ilorazu szans.

Do estymacji parametrów modelu regresji logistycznej przyjęto zestaw zmiennych objaśniajacych. Doboru zmiennych do modelu dokonano metodą selekcji wstecznej, w której sprawdzenie, czy dana zmienna podlega usunięciu, opiera się na prawdopodobieństwie statystyki Walda ${ }^{41}$. Metoda wychodzi od modelu uwzględniającego wszystkie zmienne objaśniające, a następnie stopniowo je usuwa, aby jak najlepiej dopasować model do danych empirycznych ${ }^{42}$.

Ważność modelu sprawdzono przy użyciu testu Hosmera-Lemeshowa ${ }^{43}$. Jego wartość chi-kwadrat $(>0,05)$ okazała się statystycznie nieistotna, co pozwala stwierdzić, że model został dobrze dopasowany do danych ${ }^{44}$. Poziom istotności statystycznej dla pozostania poszczególnych zmiennych w modelu ustawiono na 0,05.

Charakterystykę próby badawczej w aspekcie jakościowych zmiennych niezależnych (objaśniających) przedstawiono w tabeli 1.

39. Mikroekonometria. Modele i metody analizy danych indywidualnych, [red.] M. Gruszczyński, Wolters Kluwer, Warszawa 2012, s. 85; E. Marcinkiewicz, Uwarunkowania rozwoju dobrowolnych programów emerytalnych. Perspektywa makro- i mikroekonomiczna, Wydawnictwo Politechniki Łódzkiej, Łódź 2018, s. 228.

40. E. Gatnar, M. Walesiak, Analiza danych jakościowych i symbolicznych z wykorzystaniem programu R, CH Beck, Warszawa 2011, s. 102; G.S. Maddala, Ekonometria, PWN, Warszawa 2013, s. 373.

41. Zob. B. Danieluk, Zastosowanie regresji logistycznej w badaniach eksperymentalnych, „Psychologia Społeczna" 2010, tom 5, 2-3(14), s. 199-216.

42. P. Anioła, Z. Gołaś, Zastosowanie wielowymiarowych metod statystycznych w typologii strategii oszczędnościowych gospodarstw domowych w Polsce, "Materiały i Studia. Narodowy Bank Polski” 2012, z. 282, s. 64.

43. D.W. Hosmer, S. Lemeshow, Applied Logistic Regression, Wiley, New York 2000.

44. D. Walczak, S. Pieńkowska-Kamieniecka, Gender Differences in Financial Behaviours, "Inzinerine Ekonomika-Engineering Economics" 2018, No. 29(1), s. 125. 
Wpływ poziomu wiedzy o ubezpieczeniach społecznych na dodatkowe oszczędzanie...

Tabela 1. Zmienne jakościowe (ich warianty, liczebności i frakcje]

\begin{tabular}{|c|c|c|c|}
\hline Zmienna objaśniająca & Wariant zmiennej & $\mathrm{N}$ & $\%$ \\
\hline Płeć & $\begin{array}{l}\text { Kobieta } \\
\text { Mężczyzna }\end{array}$ & $\begin{array}{l}533 \\
497\end{array}$ & $\begin{array}{l}51,7 \\
48,3\end{array}$ \\
\hline Wiek (w latach) & $\begin{array}{l}15-24 \\
25-39 \\
40-59 \\
60 \text { i więcej }\end{array}$ & $\begin{array}{l}144 \\
300 \\
328 \\
258\end{array}$ & $\begin{array}{l}14,0 \\
29,1 \\
31,8 \\
25,0\end{array}$ \\
\hline Miejsce zamieszkania & $\begin{array}{l}\text { Wieś } \\
\text { Miasto poniżej } 100 . t y s . \text { mieszkańców } \\
\text { Miasto } 100-499 \text { tys. mieszkańców } \\
\text { Miasto } \geq 500 \text { tys. mieszkańców }\end{array}$ & $\begin{array}{l}393 \\
336 \\
177 \\
124\end{array}$ & $\begin{array}{l}38,2 \\
32,6 \\
17,2 \\
12,0\end{array}$ \\
\hline Wykształcenie & $\begin{array}{l}\text { Podstawowe } \\
\text { Zasadnicze zawodowe } \\
\text { Średnie } \\
\text { Wyższe }\end{array}$ & $\begin{array}{l}170 \\
375 \\
334 \\
149\end{array}$ & $\begin{array}{l}16,5 \\
36,5 \\
32,5 \\
14,5\end{array}$ \\
\hline Status zawodowy & $\begin{array}{l}\text { Pracuje } \\
\text { Nie pracuje } \\
\text { Emeryt/rencista } \\
\text { Uczeń/student }\end{array}$ & $\begin{array}{c}565 \\
114 \\
264 \\
72 \\
\end{array}$ & $\begin{array}{c}55,7 \\
11,2 \\
26,0 \\
7,1\end{array}$ \\
\hline Stan cywilny & $\begin{array}{l}\text { Singiel } \\
\text { Żonaty/zamężna } \\
\text { Rozwiedzional-y]/w separacji } \\
\text { Wdowa/wdowiec }\end{array}$ & $\begin{array}{c}363 \\
482 \\
70 \\
115 \\
\end{array}$ & $\begin{array}{c}35,2 \\
46,8 \\
6,8 \\
11,2\end{array}$ \\
\hline Czy ZUS jest instytucją której można ufać? & $\begin{array}{l}\text { Zdecydowanie tak } \\
\text { Raczej tak } \\
\text { Raczej nie } \\
\text { Zdecydowanie nie } \\
\text { Nie wiem/trudno powiedzieć }\end{array}$ & $\begin{array}{l}44 \\
405 \\
257 \\
197 \\
127\end{array}$ & $\begin{array}{l}4,3 \\
39,3 \\
25,0 \\
19,1 \\
12,3\end{array}$ \\
\hline $\begin{array}{l}\text { Zabezpieczenie osób starszych jest kwestią } \\
\text { ogólnospołeczną }\end{array}$ & $\begin{array}{l}\text { Zdecydowanie się nie zgadzam } \\
\text { Raczej się nie zgadzam } \\
\text { Raczej się zgadzam } \\
\text { Zdecydowanie się zgadzam } \\
\text { Nie wiem/trudno powiedzieć }\end{array}$ & $\begin{array}{c}21 \\
102 \\
492 \\
354 \\
61 \\
\end{array}$ & $\begin{array}{c}2,0 \\
9,9 \\
47,8 \\
34,4 \\
5,9\end{array}$ \\
\hline $\begin{array}{l}\text { Zabezpieczenie na starość powinno zależeć } \\
\text { wyłącznie od indywidualnej przezorności }\end{array}$ & $\begin{array}{l}\text { Zdecydowanie się nie zgadzam } \\
\text { Raczej się nie zgadzam } \\
\text { Raczej się zgadzam } \\
\text { Zdecydowanie się zgadzam } \\
\text { Nie wiem/trudno powiedzieć }\end{array}$ & $\begin{array}{l}82 \\
246 \\
431 \\
171 \\
100 \\
\end{array}$ & $\begin{array}{c}8,0 \\
23,9 \\
41,8 \\
16,6 \\
9,7\end{array}$ \\
\hline Poziom wiedzy & $\begin{array}{l}\text { Ignoranci } \\
\text { Słabo zorientowani } \\
\text { Średnio zorientowani } \\
\text { Posiadajacy wiedzę }\end{array}$ & $\begin{array}{c}131 \\
481 \\
345 \\
73 \\
\end{array}$ & $\begin{array}{c}12,7 \\
46,7 \\
33,5 \\
7,1\end{array}$ \\
\hline $\begin{array}{l}\text { Źródła wiedzy o ubezpieczeniach społecznych - } \\
\text { kontakt z ZUS }\end{array}$ & $\begin{array}{l}\text { Tak } \\
\text { Nie }\end{array}$ & $\begin{array}{l}174 \\
856\end{array}$ & $\begin{array}{l}16,9 \\
83,1\end{array}$ \\
\hline $\begin{array}{l}\text { Źródła wiedzy o ubezpieczeniach społecznych - } \\
\text { ze szkoły/studiów }\end{array}$ & $\begin{array}{l}\text { Tak } \\
\text { Nie }\end{array}$ & $\begin{array}{c}12 \\
1018 \\
\end{array}$ & $\begin{array}{c}1,2 \\
98,8 \\
\end{array}$ \\
\hline $\begin{array}{l}\text { Źródła wiedzy o ubezpieczeniach społecznych - } \\
\text { rozmowy z rodziną/znajomymi }\end{array}$ & $\begin{array}{l}\text { Tak } \\
\text { Nie } \\
\end{array}$ & $\begin{array}{l}126 \\
904 \\
\end{array}$ & $\begin{array}{l}12,2 \\
87,8\end{array}$ \\
\hline $\begin{array}{l}\text { Źródła wiedzy o ubezpieczeniach społecznych - } \\
\text { czasopisma specjalistyczne o profilu ekonomicznym }\end{array}$ & $\begin{array}{l}\text { Tak } \\
\text { Nie } \\
\end{array}$ & $\begin{array}{c}24 \\
1006 \\
\end{array}$ & $\begin{array}{l}2,3 \\
97,7\end{array}$ \\
\hline $\begin{array}{l}\text { Źródła wiedzy o ubezpieczeniach społecznych - blogi, } \\
\text { strony internetowe }\end{array}$ & $\begin{array}{l}\text { Tak } \\
\text { Nie }\end{array}$ & $\begin{array}{c}16 \\
1014\end{array}$ & $\begin{array}{c}1,6 \\
98,4\end{array}$ \\
\hline $\begin{array}{l}\text { Źródła wiedzy o ubezpieczeniach społecznych - } \\
\text { rozmowy ze specjalistami }\end{array}$ & $\begin{array}{l}\text { Tak } \\
\text { Nie }\end{array}$ & $\begin{array}{l}42 \\
988\end{array}$ & $\begin{array}{c}4,1 \\
95,9\end{array}$ \\
\hline $\begin{array}{l}\text { Źródła wiedzy o ubezpieczeniach społecznych - } \\
\text { żadne, nie szukam wiedzy }\end{array}$ & $\begin{array}{l}\text { Tak } \\
\text { Nie }\end{array}$ & $\begin{array}{l}475 \\
555\end{array}$ & $\begin{array}{l}46,1 \\
53,9\end{array}$ \\
\hline
\end{tabular}

Źródło: opracowanie własne na podstawie bazy danych udostępnionej przez ZUS. 
Grupami referencyjnymi, względem których analizowano wyniki modelu regresji logistycznej, były: kobiety; osoby w wieku 60 lat i więcej; mieszkańcy miast powyżej 500 tys. mieszkańców; z wykształceniem wyższym; pracujący; osoby owdowiałe; osoby, które nie wiedziały, bądź trudno im było powiedzieć, czy ZUS jest instytucją, której można ufać, jak również ustosunkować się do stwierdzenia, że zabezpieczenie osób starszych jest kwestią ogólnospołeczną oraz że zabezpieczenie na starość powinno zależeć wyłącznie od indywidualnej przezorności; posiadający wiedzę o ubezpieczeniach społecznych. Kategoriami referencyjnymi były ponadto osoby czerpiące wiedzę o ubezpieczeniach społecznych poprzez kontakt z ZUS-em (z pracownikami, w placówce, telefoniczny), ze szkoły / studiów, z czasopism specjalistycznych o tematyce ekonomicznej, blogów i tematycznych stron internetowych, jak również rozmów ze specjalistami (np. księgowymi), oraz osoby, które nie rozmawiały na tematy z zakresu ubezpieczeń społecznych z rodziną lub znajomymi. W dalszej części opracowania grupy te określono jako „ref.”.

Charakterystyka ilościowej zmiennej objaśniającej została przestawiona w tabeli 2.

Tabela 2. Zmienna ilościowa - charakterystyka

\begin{tabular}{|l|l|c|l|}
\hline \multicolumn{1}{|c|}{ Zmienna objaśniająca } & \multicolumn{1}{|c|}{ Wariant zmiennej } & N & \multicolumn{1}{c|}{ Wartości } \\
\hline $\begin{array}{l}\text { Dochód gospodarstwa } \\
\text { domowego }\end{array}$ & $\begin{array}{l}\text { w tys. zł/1 os. w gospodarstwie } \\
\text { domowym }\end{array}$ & 1030 & $\begin{array}{l}\text { Min. 0,08; Max. 7,50; Średnia } \\
\text { 1,80; Odchyl. stand. 1,00 }\end{array}$ \\
\hline
\end{tabular}

Źródło: opracowanie własne na podstawie bazy danych udostępnionej przez ZUS.

Należy zaznaczyć, że w celu dokonania analizy zależności pomiędzy poziomem wiedzy o ubezpieczeniach społecznych a cechami demograficznymi respondentów, jak również dla zbadania, czy na poziom wiedzy wpływają źródła jej pozyskania, zastosowano test niezależności chi-kwadrat.

Poziom wiedzy z powyższego badania określono tzw. indeksem wiedzy opracowanym przez Instytut Spraw Publicznych (ISP) ${ }^{45}$. W badaniu respondenci mogli uzyskać maksymalnie 50 punktów odpowiadając na zadanych im łącznie 15 pytań, dotyczących m.in. rodzaju i przedmiotu świadczeń oferowanych z ubezpieczeń społecznych, organizacji systemu ubezpieczeń społecznych, zadań realizowanych przez Zakład Ubezpieczeń Społecznych, składek na ubezpieczenie społeczne, obowiązku objęcia ubezpieczeniem społecznym, dodatkowego zabezpieczenia emerytalnego, dostępu do świadczeń z polskiego systemu ubezpieczeń społecznych na obszarze Unii Europejskiej, jak również korzystania z uprawnień z systemów innych państw UE ${ }^{46}$. Następnie, w zależności od wyniku uzyskanego w teście wiedzy (według odsetka poprawnie udzielonych odpowiedzi), respondenci zgodnie z koncepcją ISP zostali podzielenie na pięć grup. Grupy te to: ignoranci $(<10 \%)$, słabo zorientowani (10-40\%), średnio zorientowani (40-60\%), posiadający wiedzę (60-90\%) oraz eksperci (pow. 90\%). Ten podział przyjęto również w ramach niniejszego opracowania.

Wszystkie obliczenia zaprezentowane w artykule wykonano za pomoca programu IBM SPSS Statistics 26.0.

45. Autorki niniejszego artykułu składaja podziękowania pracownikom ZUS oraz Instytutu Spraw Publicznych za udzielone wyjaśnienia w zakresie sposobu obliczenia indeksu wiedzy i ustalenia przedziałów punktacji dla poszczególnych kategorii respondentów według uzyskanego przez nich wyniku w teście wiedzy, tj.: ignoranci, słabo zorientowani, średnio zorientowani, posiadający wiedzę, eksperci.

46. R. Marczak, Przeglqd badań dotyczqcych wiedzy i postaw Polaków wobec ubezpieczeń społecznych, ZUS, Kraków, 7 marca 2018, https://www.zus.pl/documents/10182/1507934/02+-+Robert+Marczak.pdf/b751258d-c30a-4c2d-bb16-42cd647fee71 [dostęp: 18.12.2021]. 


\section{Wyniki badań}

Z przeprowadzonych badań wynika przede wszystkim, że jedynie 24,4\% badanych zadeklarowało, że oszczędza dodatkowo na starość. Można zatem stwierdzić, że trzech na czterech respondentów nie ma żadnego dodatkowego, poza uczestnictwem w publicznym systemie emerytalnym, zabezpieczenia finansowego na okres po zaprzestaniu aktywności zawodowej. Najczęściej wskazywaną tego przyczyna ${ }^{47}$ są za niskie zarobki, a tym samym brak przychodu, aby móc jeszcze odłożyć jakiekolwiek środki finansowe na starość (rys. 1.).

\section{Rysunek 1. Powody nieoszczędzania na starość podawane przez respondentów [w \%]}

Za mało zarabiam i nie jestem w stanie nic odłożyć

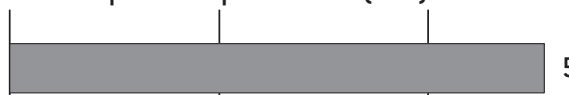

Dysponuję odpowiednimi środkami, by oszczędzać, ale nie jest to dla mnie istotny ce

Nie wiem, na czym taki sposób oszczędzania polega lub jak go zorganizować

Dysponuję odpowiednimi środkami, by oszczędzać, ale obecnie oszczędzam na inny ce

Dysponuję odpowiednimi środkami, by oszczędzać, ale emerytura to zbyt odległa perspektywa, żeby myśleć teraz o oszczędzaniu

Inne

e

10,4 18,7

$0 \%$

2,6

2,2

1,8

10,2

$20 \%$

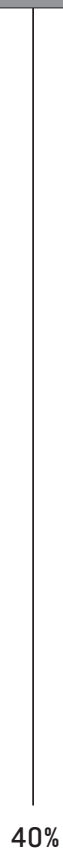

$40 \%$ $\mid$

$60 \%$

Źródło: opracowanie własne na podstawie bazy danych udostępnionej przez ZUS.

Można ponadto zauważyć, że zaledwie ok. 13\% respondentów liczy na to, że emerytura z publicznego systemu emerytalnego (administrowanego przez ZUS) zapewni im odpowiedni poziom życia w okresie starości. Jednocześnie, co jest pozytywnym zjawiskiem, niewielu badanych stwierdza, że oszczędzanie na starość nie jest dla nich istotne, albo że emerytura jest zbyt odległa, aby o niej myśleć już teraz. W kontekście takich odpowiedzi ważniejszym powodem nieoszczędzania wydaje się być zatem ponownie brak odpowiednich środków finansowych.

47. Z ogółu respondentów, którzy udzielili odpowiedni na pytanie dotyczące przyczyn nieoszczędzania ( $N=$ ?79), wybrano tylko te osoby, które wskazały wyłącznie na jedną przyczynę nieoszczędzania ( $\mathrm{N}=$ ?22). 
Aby zbadać, czy wiedza istotnie statycznie oddziałuje na oszczędzanie na starość, najpierw jednak należało określić, jaką w ogóle wiedzę o systemie ubezpieczeń społecznych maja ankietowani. Biorąc pod uwagę indeks wiedzy, z badań wynika, że niemal co drugi Polak $(46,7 \%$ jest słabo zorientowany w ubezpieczeniach społecznych, 33,5\% jest średnio zorientowanych, a 12,7\% respondentów okazało się być ignorantami. Wśród badanych nie było ani jednej osoby, którą można określić mianem eksperta z ubezpieczeń społecznych, a tylko ok. 7\% stanowiły osoby posiadające wiedzę, np. o rodzajach i wysokości składek na ubezpieczenie społeczne (w tym na ubezpieczenie emerytalne]. Jest to szczególnie istotne, gdyż to właśnie wśród osób z wyższą wiedza jest zdecydowanie najwięcej osób deklarujących oszczędzanie na starość $(43,8 \%$ ) (rys. 2.).

\section{Rysunek 2. Oszczędzanie na starość a poziom wiedzy o ubezpieczeniach społecznych [w \%]}

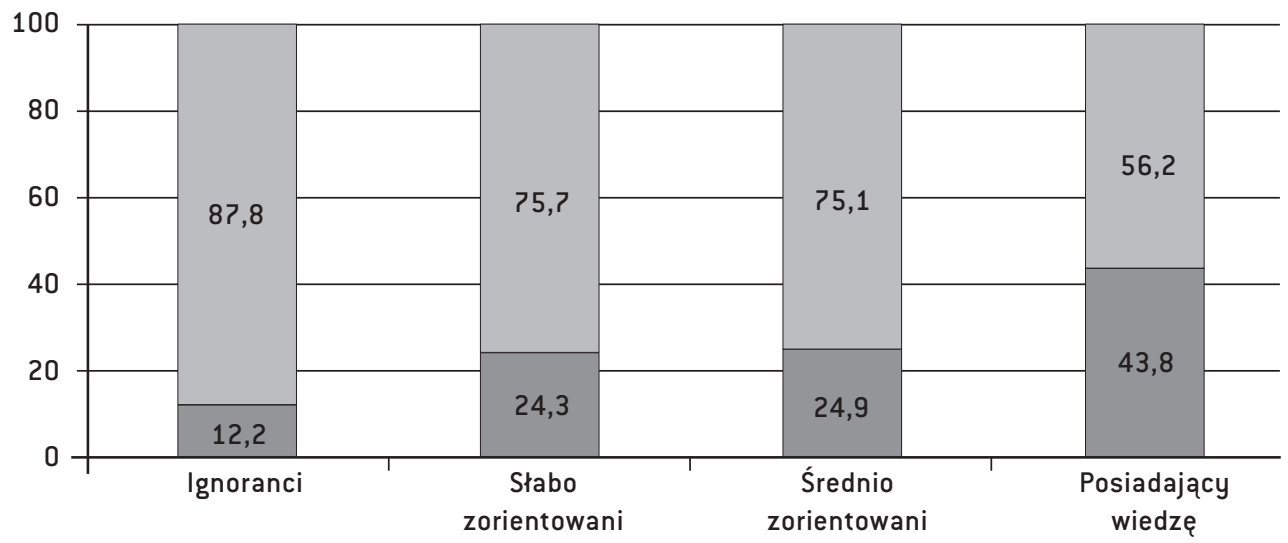

Oszczędza na starość $\square$ Nie oszczędza na starość

Źródło: opracowanie własne na podstawie bazy danych udostępnionej przez ZUS.

Z powyższych danych wynika zasadniczy wniosek. Podczas gdy wśród ignorantów zaledwie co dziesiąta osoba przyznaje, że odkłada dodatkowe środki na starość, to wśród osób posiadajacych wiedzę jest to niemal co druga osoba.

W dalszej części opracowania przeprowadzono analizę w celu zbadania, jakie zmienne demograficzne (przedstawione w tab. 1.) istotnie statystycznie wpływaja na poziom posiadanej wiedzy o ubezpieczeniach społecznych. Przeprowadzony test niezależności chi-kwadrat wykazał, że są to płeć, wiek, miejsce zamieszkania i wykształcenie respondenta (poziom istotności był niższy niż 0,05).

Biorąc pod uwagę płeć $\left(\chi^{2}=9,621\right.$, V-Cramer=0,097, $\left.p=0,022\right)$, stwierdzono, że kobiety częściej niż mężczyźni zaliczają się do tzw. ignorantów. Wśród mężczyzn natomiast większy odsetek, w porównaniu do kobiet, stanowią osoby posiadające wiedzę. Biorąc natomiast pod uwagę wiek respondenta $\left(\chi^{2}=50,690\right.$, V-Cramer $\left.=0,128, p=0,000\right)$, wykazano, że największy odsetek osób posiadających wiedzę występuje w grupie osób w wieku 25-39 lat (10,0\%) oraz 40-59 lat (7,3\%). Najmniejszą wiedzę natomiast najczęściej posiadają osoby młode (do 24 lat) oraz najstarsze (w wieku 60 lat i więcej). Szczegółową strukturę respondentów, z uwzględnieniem ich płci oraz wieku, przedstawiono w tabeli 3. 
Wpływ poziomu wiedzy o ubezpieczeniach społecznych na dodatkowe oszczędzanie...

Tabela 3. Poziom wiedzy o ubezpieczeniach społecznych a wiek i płeć respondentów

\begin{tabular}{|c|c|c|c|c|c|c|}
\hline \multirow[b]{2}{*}{ Wyszczególnienie } & \multicolumn{2}{|c|}{ Płeć } & \multicolumn{4}{|c|}{ Wiek } \\
\hline & Kobiety & Mężczyźni & 15-24 lata & 25-39 lat & $40-59$ lat & $\begin{array}{l}60 \text { lat } \\
\text { i więcej }\end{array}$ \\
\hline Ignoranci & $15,8 \%$ & $9,5 \%$ & $27,1 \%$ & $6,0 \%$ & $11,9 \%$ & $13,6 \%$ \\
\hline Słabo zorientowani & $44,3 \%$ & $49,3 \%$ & $48,6 \%$ & $47,3 \%$ & $44,5 \%$ & $47,7 \%$ \\
\hline Średnio zorientowani & $33,2 \%$ & $33,8 \%$ & $20,8 \%$ & $36,7 \%$ & $36,3 \%$ & $33,3 \%$ \\
\hline Posiadający wiedzę & $6,8 \%$ & $7,4 \%$ & $3,5 \%$ & $10,0 \%$ & $7,3 \%$ & $5,4 \%$ \\
\hline
\end{tabular}

Źródło: opracowanie własne na podstawie bazy danych udostępnionej przez ZUS.

Z przeprowadzonego badania wyraźnie wynika ponadto, że wraz z poziomem wykształcenia zmniejsza się odsetek osób z niską wiedzą o ubezpieczeniach społecznych, a tym samym zwiększa się odsetek osób co najmniej średnio zorientowanych w tej tematyce $\left(\chi^{2}=65,289\right.$, $V$-Cramer $=0,145$, $\mathrm{p}=0,000$ ). Wśród osób z wykształceniem wyższym 12,8\% posiadało wiedzę o ubezpieczeniach społecznych, podczas gdy wśród osób z wykształceniem podstawowym było to zaledwie 1,2\% respondentów. Ponadto zaobserwowano, że poziom wiedzy jest najwyższy wśród mieszkańców największych miast ( $\chi^{2}=23,652, V$-Cramer $\left.=0,087, p=0,005\right)$. Odsetek osób określanych ignorantami w zakresie wiedzy o ubezpieczeniach społecznych jest największy wśród osób mieszkających na wsi $[16,5 \%$ ), natomiast wśród osób posiadających wiedzę przeważają mieszkańcy miast pow. 500 tys. osób $(13,7 \%)$. Szczegółową strukturę respondentów, zważywszy na ich wykształcenie i miejsce zamieszkania, przedstawiono w tabeli 4.

Tabela 4. Poziom wiedzy o ubezpieczeniach społecznych a wykształcenie i miejsce zamieszkania respondentów

\begin{tabular}{|l|c|c|c|c|c|c|c|c|}
\hline \multirow{2}{*}{ Wyszczególnienie } & \multicolumn{4}{|c|}{ Wykształcenie } & \multicolumn{4}{c|}{ Miejsce zamieszkania } \\
\cline { 2 - 9 } & Podstawowe & Zawodowe & Średnie & Wyższe & Wieś & $\begin{array}{c}\text { miasto } \\
<100 \\
\text { tys. 0sób }\end{array}$ & $\begin{array}{c}\text { miasto } \\
100-499 \\
\text { tys. 0sób }\end{array}$ & $\begin{array}{c}\text { miasto } \\
\geq 500 \\
\text { tys. 0sób }\end{array}$ \\
\hline Ignoranci & $25,9 \%$ & $10,7 \%$ & $12,9 \%$ & $2,7 \%$ & $16,5 \%$ & $9,5 \%$ & $13,0 \%$ & $8,9 \%$ \\
\hline Słabo zorientowani & $45,3 \%$ & $52,0 \%$ & $44,0 \%$ & $40,3 \%$ & $49,1 \%$ & $45,5 \%$ & $46,3 \%$ & $42,7 \%$ \\
\hline Średnio zorientowani & $27,6 \%$ & $31,5 \%$ & $34,1 \%$ & $44,3 \%$ & $28,8 \%$ & $38,1 \%$ & $34,5 \%$ & $34,7 \%$ \\
\hline Posiadający wiedzę & $1,2 \%$ & $5,9 \%$ & $9,0 \%$ & $12,8 \%$ & $5,6 \%$ & $6,8 \%$ & $6,2 \%$ & $13,7 \%$ \\
\hline
\end{tabular}

Źródło: opracowanie własne na podstawie bazy danych udostępnionej przez ZUS.

W kolejnej części badania, na podstawie modelu regresji logistycznej, skoncentrowano się na kwestii, czy i jak posiadana przez respondentów wiedza o ubezpieczeniach społecznych oraz sposób jej pozyskiwania wpływa na gromadzenie dodatkowych oszczędności na starość. W tym celu zmienne te zestawiono z innymi cechami społeczno-demograficznymi respondentów. W tabeli 5. przedstawiono tylko te zmienne objaśniające, które okazały się istotne statystycznie. 
Tabela 5. Wyniki modelu regresji logistycznej dla oszczędzania na starość

\begin{tabular}{|c|c|c|c|c|}
\hline Zmienna & $\begin{array}{c}\text { Bład } \\
\text { standardowy }\end{array}$ & $\begin{array}{c}\text { Symbol } \\
\text { istotnościa }\end{array}$ & \begin{tabular}{|c|} 
Poziom \\
istotności \\
$(p]$
\end{tabular} & $\operatorname{Exp}(B)$ \\
\hline $\begin{array}{l}\text { Miejsce zamieszkania (ref.: miasta>500 tys. mieszkańców) } \\
\text { wieś } \\
\text { miasta }<100 \text { tys. mieszkańców } \\
\text { miasta } 100-500 \text { tys. mieszkańców }\end{array}$ & $\begin{array}{l}\text {,245 } \\
\text {,246 } \\
\text {,284 }\end{array}$ & $\begin{array}{l} \\
* * \\
* \\
*\end{array}$ & $\begin{array}{l}, 043 \\
, 008 \\
, 049 \\
, 016\end{array}$ & $\begin{array}{l}, 522 \\
, 616 \\
, 503\end{array}$ \\
\hline $\begin{array}{l}\text { Status zawodowy (ref.: pracuje) } \\
\text { nie pracuje } \\
\text { emeryt/rencista } \\
\text { uczeń/student }\end{array}$ & $\begin{array}{l}, 293 \\
, 200 \\
, 369\end{array}$ & $\begin{array}{c}* \\
* \\
* \\
*\end{array}$ & $\begin{array}{l}, 019 \\
, 039 \\
, 007 \\
, 273\end{array}$ & $\begin{array}{l}, 547 \\
, 585 \\
, 667\end{array}$ \\
\hline $\begin{array}{l}\text { Zaufanie do ZUS (ref.: nie wiem/trudno powiedzieć) } \\
\text { zdecydowanie tak } \\
\text { raczej tak } \\
\text { raczej nie } \\
\text { zdecydowanie nie }\end{array}$ & $\begin{array}{l}, 478 \\
, 316 \\
, 321 \\
, 327\end{array}$ & $* *$ & $\begin{array}{l}, 008 \\
, 507 \\
, 738 \\
, 053 \\
, 020 \\
\end{array}$ & $\begin{array}{l}1,373 \\
1,111 \\
1,862 \\
2,142\end{array}$ \\
\hline $\begin{array}{l}\text { Zabezpieczenie osób starszych jest kwestią ogólnospołeczną } \\
\text { (ref.: trudno powiedzieć) } \\
\text { zdecydowanie się nie zgadzam } \\
\text { raczej się nie zgadzam } \\
\text { raczej się zgadzam } \\
\text { zdecydowanie się zgadzam }\end{array}$ & $\begin{array}{l}, 640 \\
, 460 \\
, 422 \\
, 437\end{array}$ & $\begin{array}{c}* * * \\
*\end{array}$ & $\begin{array}{l}, 000 \\
, 020 \\
, 517 \\
, 787 \\
, 152 \\
\end{array}$ & $\begin{array}{l}4,426 \\
1,347 \\
, 892 \\
, 535\end{array}$ \\
\hline $\begin{array}{l}\text { Zabezpieczenie na starość powinno zależeć wyłacznie } \\
\text { od indywidualnej przezorności (ref.: trudno powiedzieć) } \\
\text { zdecydowanie się nie zgadzam } \\
\text { raczej się nie zgadzam } \\
\text { raczej się zgadzam } \\
\text { zdecydowanie się zgadzam }\end{array}$ & $\begin{array}{l}, 435 \\
, 389 \\
, 357 \\
, 388 \\
\end{array}$ & $\begin{array}{l}* \\
* \\
\end{array}$ & $\begin{array}{l}, 001 \\
, 141 \\
, 813 \\
, 049 \\
, 048 \\
\end{array}$ & $\begin{array}{c}1,896 \\
, 912 \\
2,016 \\
2,156\end{array}$ \\
\hline $\begin{array}{l}\text { Wiedza (ref.: posiadający wiedzę) } \\
\text { ignoranci } \\
\text { słabo zorientowani } \\
\text { średnio zorientowani }\end{array}$ & $\begin{array}{l}, 403 \\
, 284 \\
, 290 \\
\end{array}$ & $\begin{array}{l}* * \\
* * \\
* * \\
\end{array}$ & $\begin{array}{l}, 004 \\
, 001 \\
, 001 \\
, 002 \\
\end{array}$ & $\begin{array}{l}, 271 \\
, 402 \\
, 401 \\
\end{array}$ \\
\hline $\begin{array}{l}\text { Źródło wiedzy o ubezpieczeniach społecznych - rodzina } \\
\text { i znajomi (ref.: nie) }\end{array}$ & ,266 & $*$ & 029 & ,558 \\
\hline $\begin{array}{l}\text { Źródło wiedzy o ubezpieczeniach społecznych - żadne, nie } \\
\text { szukam wiedzy (ref.: tak) }\end{array}$ & 174 & $* *$ & ,006 & 1,616 \\
\hline Stała &,- 443 & & ,451 & ,642 \\
\hline R-kwadrat Coxa i Snella & \multicolumn{4}{|c|}{112} \\
\hline R-kwadrat Nagelkerkego & \multicolumn{4}{|c|}{167} \\
\hline Test Hosmera-Lemeshowa ( $p$-value) & \multicolumn{4}{|c|}{, 567} \\
\hline-2 logarytm wiarygodności & \multicolumn{4}{|c|}{1000,984} \\
\hline $\mathrm{N}$ & \multicolumn{4}{|c|}{1013} \\
\hline
\end{tabular}

a Określany następująco: *** dla $p<0,001 ;{ }^{* *}$ dla $p<0,01 ;{ }^{*}$ dla $p<0,05$

Źródło: opracowanie własne na podstawie bazy danych udostępnionej przez ZUS.

Z przeprowadzonej analizy regresji logistycznej wynika, że wśród zmiennych demograficznych dla oszczędzania na starość istotne statystycznie okazało się miejsce zamieszkania oraz status zawodowy respondenta. Zdecydowanie największe szanse na dodatkowe oszczędzanie o celu emerytalnym mają osoby z miast liczących powyżej 500 tys. mieszkańców, tj. o ok. 48\% większe niż w przypadku osób ze wsi. Z kolei osoby z najmniejszych miast (poniżej 100 tys. mieszkańców) 
mają o ok. 38\% niższe szanse na oszczędzanie niż osoby z największych miast. Ponadto szanse te są niższe wśród osób niepracujacych (o ok. 45\%) oraz emerytów i rencistów (o ok. 42\%) w porównaniu do grupy referencyjnej, tj. osób pracujących. Dla dodatkowego oszczędzania na starość istotny okazał się poziom zaufania do Zakładu Ubezpieczeń Społecznych. Osoby, które zdecydowanie nie ufają tej instytucji, mają ponad dwukrotnie (o 114\%) większe szanse na gromadzenie dodatkowych oszczędności emerytalnych w stosunku do osób, które nie mają zdania na ten temat. Biorąc ponadto pod uwagę nastawienie respondentów do tego, kto powinien odpowiadać za zabezpieczenie osób starszych, z przeprowadzonej analizy jednoznacznie wynika, że oszczędzaja przede wszystkim osoby zdecydowanie niezgadzające się ze stwierdzeniem, że jest to kwestia ogólnospołeczna. Ich szanse na oszczędzanie są aż ponad 4-krotnie większe niż osób, które nie maja zdania na ten temat. Analogicznie: największe szanse na gromadzenie środków na starość poza publicznym systemem emerytalnym (o 115\%) maja osoby, które zdecydowanie uważaja, że powinno to zależeć od poszczególnych osób i ich indywidualnej przezorności.

Ważnych wniosków, w kontekście tematyki niniejszego artykułu, dostarcza badanie w zakresie wiedzy. Okazuje się, że posiadanie wiedzy o ubezpieczeniach społecznych jest kluczowe dla oszczędzania na starość. Osoby o najmniejszej wiedzy w tym zakresie mają najmniejsze szanse na dodatkowe zabezpieczenie emerytalne. Wśród tzw. ignorantów szanse te są niższe o ok. 73\%, a w przypadku słabo i średnio zorientowanych w tematyce ubezpieczeń społecznych - o ok. 60\% niższe w porównaniu do osób posiadających wiedzę.

Jeśli chodzi o źródła wiedzy o ubezpieczeniach społecznych, to istotny statystycznie jest wpływ rodziny i znajomych. Okazuje się, że osoby, które wiedzę o systemie ubezpieczeń społecznych czerpią właśnie od nich, mają o ok. 44\% niższe szanse na oszczędzanie na starość w stosunku do osób, dla których nie jest to źródło informacji na ten temat. Istotnych statystycznie wniosków i zarazem ważnych z punktu widzenia skłonności do oszczędzania dostarcza fakt, że już sam brak poszukiwania informacji o ubezpieczeniach społecznych wpływa na mniejszą skłonność do oszczędzania na starość. Z wyników regresji logistycznej wynika bowiem, że osoby, które poszukują wiedzy o ubezpieczeniach społecznych, mają o ok. 62\% większe szanse na gromadzenie dodatkowego kapitału na okres po zakończeniu aktywności zawodowej, od osób, które tego nie robia.

W ostatnim etapie przeprowadzonego badania spróbowano określić, czy istnieje jakiś związek między posiadaną wiedzą o ubezpieczeniach społecznych a źródłami jej pozyskiwania. W analizie wzięto pod uwagę te same źródła informacji, które uwzględniono już w analizie regresji logistycznej dla zbadania ich wpływu na dodatkowe oszczędzanie na starość. Tabela 6. przedstawia strukturę respondentów w zależności od poziomu ich wiedzy i źródeł jej pozyskiwania. Wskazano tylko te zależności, które okazały się istotne statystycznie.

Tabela 6. Poziom wiedzy o ubezpieczeniach społecznych a źródła jej pozyskania

\begin{tabular}{|l|c|c|c|c|c|c|}
\hline \multirow{2}{*}{ Wyszczególnienie } & \multicolumn{2}{|c|}{ Kontakt z ZUS } & \multicolumn{2}{c|}{ Rozmowy ze specjalistami } & \multicolumn{2}{c|}{ Rozmowy z rodziną/znajomymi } \\
\cline { 2 - 7 } & Nie & Tak & Nie & Tak & Nie & Tak \\
\hline Ignoranci & $14,1 \%$ & $5,7 \%$ & $13,2 \%$ & $2,4 \%$ & $14,2 \%$ & $2,4 \%$ \\
\hline Słabo zorientowani & $48,7 \%$ & $36,8 \%$ & $47,3 \%$ & $33,3 \%$ & $47,8 \%$ & $38,1 \%$ \\
\hline Średnio zorientowani & $30,7 \%$ & $47,1 \%$ & $32,6 \%$ & $52,4 \%$ & $31,1 \%$ & $50,8 \%$ \\
\hline Posiadający wiedzę & $6,5 \%$ & $10,4 \%$ & $6,9 \%$ & $11,9 \%$ & $6,9 \%$ & $8,7 \%$ \\
\hline
\end{tabular}

Źródło: opracowanie własne na podstawie bazy danych udostępnionej przez ZUS. 
Z powyższych danych wynika, że na poziom wiedzy o ubezpieczeniach społecznych wpływa wiedza pozyskana w kontakcie z pracownikami ZUS (w placówce lub przez kontakt telefoniczny) $\left(\chi^{2}=27,159\right.$, V-Cramer=0,162, $p=0,000$ ), rozmowy ze specjalistami ( $\mathrm{np}$. księgowymi w miejscu pracy, czy pracownikami biur podatkowych $)\left(\chi^{2}=11,450\right.$, V-Cramer $\left.=0,105, p=0,010\right)$ oraz z rodzinạ lub znajomymi ( $\chi^{2}=27,710, \mathrm{~V}$-Cramer=0,164, $\left.\mathrm{p}=0,000\right)$. Wśród osób, które nie czerpią wiedzy z powyższych źródeł informacji, zdecydowanie więcej jest osób określanych jako ignoranci i słabo zorientowani w ubezpieczeniach społecznych. Z drugiej strony, wśród osób korzystających z tych źródeł wiedzy zdecydowanie więcej jest osób średnio zorientowanych i posiadających wiedzę. Nieistotne statystycznie okazały się natomiast takie źródła wiedzy, jak: szkoła/studia, czytanie specjalistycznej prasy o tematyce ekonomicznej, jak również blogów i stron internetowych.

W kontekście źródeł wiedzy o ubezpieczeniach społecznych z badań wynika jeszcze inny istotny wniosek. Wśród źródeł informacji, które są dla Polaków najbardziej wiarygodne i którym ufają oni najbardziej, są: kontakt z pracownikami ZUS (12,7\%) oraz z rodziną i znajomymi $[5,0 \%$ ). Ponadto okazuje się, że Polacy ufają również informacjom przekazywanym w telewizji $(10,6 \%)$. Respondenci wypowiedzieli się także w kwestii, z których źródeł chcieliby uzyskiwać wiedzę o ubezpieczeniach społecznych, a w związku z tym - również o systemie emerytalnym i oszczędzaniu na starość (rys. 3.).

\section{Rysunek 3. Wybrane, pożądane przez respondentów źródła wiedzy o ubezpieczeniach społecznych* [w \%)}

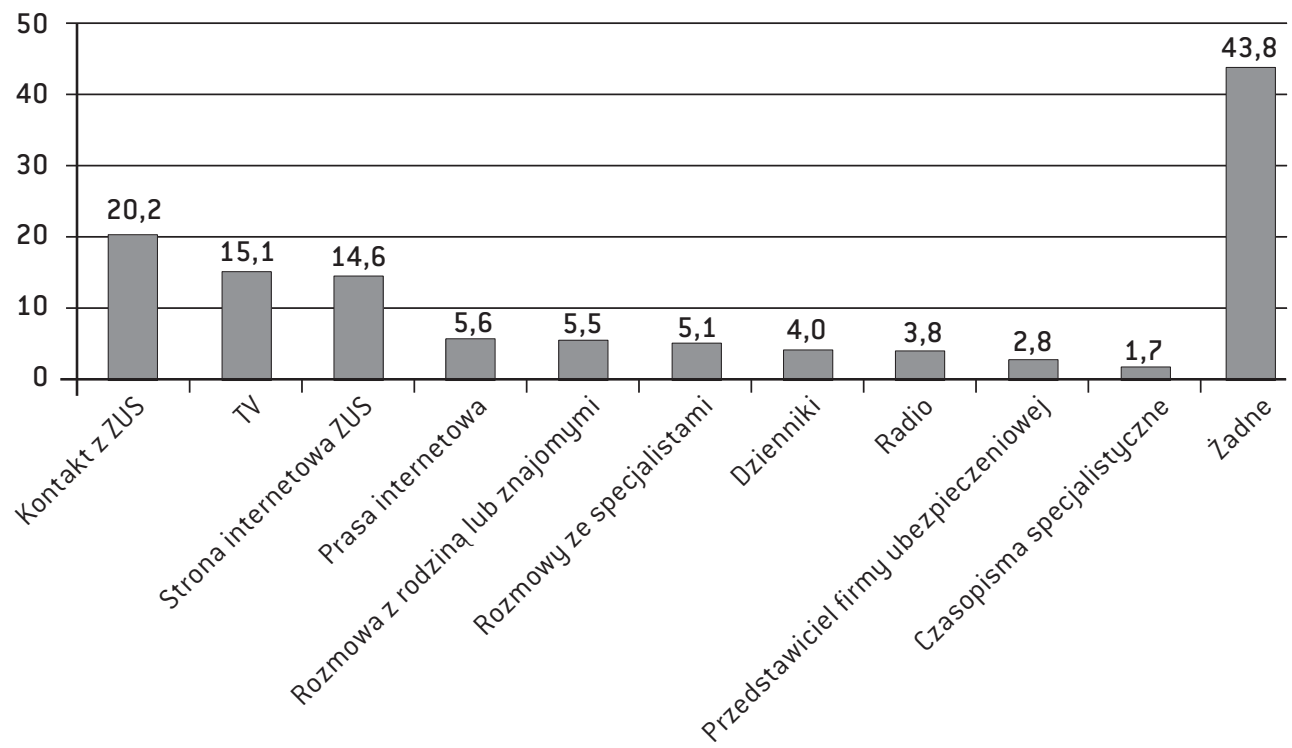

*Respondenci ( $\mathrm{N}=1030$ ) wskazywali więcej niż jedną odpowiedź.

Źródło: opracowanie własne na podstawie bazy danych udostępnionej przez ZUS.

Z powyższych danych wynika, że respondenci wiedzę o ubezpieczeniach społecznych zdecydowanie najbardziej chca pozyskiwać poprzez kontakt tradycyjny z pracownikami ZUS (osobiście w placówce lub przez telefon], poprzez stronę internetową ZUS, jak również z telewizji. Niemniej 
Wpływ poziomu wiedzy o ubezpieczeniach społecznych na dodatkowe oszczędzanie...

należy zwrócić uwagę na niepokojący fakt, że ponad 40\% Polaków w ogóle nie jest zainteresowana poszukiwaniem i uzupełnianiem wiedzy o ubezpieczeniach społecznych z jakichkolwiek źródeł.

\section{Podsumowanie}

Wyniki badań przedstawione w niniejszym artykule wskazują, że na oszczędzanie na starość wpływają różne zmienne społeczno-demograficzne. Okazały się nimi miejsce zamieszkania, sytuacja zawodowa badanych, stopień zaufania do ZUS, podejście do kwestii, kto powinien zadbać o zabezpieczenie finansowe osób starszych, poziom wiedzy o ubezpieczeniach społecznych, jak również rodzaje źródeł, z których jest ona czerpana.

Okazuje się, że wraz z wyższym poziomem wiedzy o ubezpieczeniach społecznych zwiększa się również skłonność do oszczędzania. Osoby najmniej zorientowane w tej tematyce mają aż o ponad 70\% niższe szanse na oszczędzanie na starość od osób posiadających wiedzę o ubezpieczeniach społecznych. Tym samym potwierdzona została hipoteza pierwsza, mówiąca o tym, że poziom wiedzy o ubezpieczeniach społecznych Polaków wpływa istotnie na ich skłonność do oszczędzania na starość. Ma to swoje potwierdzenie również w innych badaniach, jak na przykład przeprowadzonych przez Tabeę Bucher-Koenen ${ }^{48}$, która również wskazuje na pozytywną korelację między kompetencjami finansowymi a dodatkowym oszczędzaniem na starość. Podobnie dowodzi Chiara Monticone ${ }^{49}$ : że wiedza finansowa jest podstawą dobrobytu finansowego.

Z zaprezentowanych badań wynika również, że osoby, które w ogóle nie starają się zdobywać wiedzy o ubezpieczeniach społecznych, a zatem nie korzystają z żadnych źródeł informacji, maja zdecydowanie (o ok. 60\%) mniejsze szanse na oszczędzanie na starość od osób, które tej wiedzy poszukują. Ponadto spośród różnego rodzaju źródeł informacji na dodatkowe zabezpieczenie emerytalne wpływa wiedza przekazywana przez rodzinę i znajomych. Wraz z takimi źródłami informacji, jak kontakt z ZUS i rozmowy ze specjalistami, rodzina i znajomi są tymi kanałami pozyskiwania informacji o ubezpieczeniach społecznych, które determinują wyższy poziom wiedzy na ich temat. Tym samym potwierdzona została także hipoteza druga.

Na koniec należy zaznaczyć, że autorki niniejszego opracowania zdają sobie sprawę z pewnych jego ograniczeń. Po pierwsze, ponieważ w powyższych obliczeniach skorzystano z bazy danych udostępnionej przez ZUS, nie mogły zostać zanalizowane takie potencjalnie istotne zmienne, jak np. zaufanie Polaków do systemu emerytalnego czy poziom satysfakcji badanych z własnej sytuacji materialnej. Po drugie, badaniem objęta została wyłącznie ludność Polski, jednakże ze względu na to, że badanie jest reprezentatywne, jego wyniki moga mieć praktyczne i szerokie znaczenie również dla innych krajów, zarówno w zakresie dodatkowego oszczędzania na emeryturę, jak i polityki edukacyjnej w obszarze finansów publicznych i prywatnych. Jednakowoż w kontekście rynku polskiego wnioski z badań wydaja się być szczególnie istotne dla instytucji prywatnego sektora finansowego, w tym również dla zakładów ubezpieczeń na życie, które angażując się

48. T. Bucher-Koenen, Financial Literacy and Private Old-Age Provision in Germany. Evidence from SAVE 2008, "Mannheim Research Institute for the Economics of Aging" 2009, https://madoc.bib.uni-mannheim.de/2572/1/ meadp_192_09.pdf [dostęp: 15.07.2021].

49. C. Monticone, How Much Does Wealth Matter in the Acquisition of Financial Literacy?, „The Journal of Consumer Affairs" 2010, №. 44[2]. 
w oferowanie produktów emerytalnych powinny mieć na względzie skłonność Polaków do dodatkowego oszczędzania na starość oraz preferowane przez nich źródła informacji (wiedzy) na tematy finansowe (ubezpieczeniowe). Dzięki temu będą mogły trafniej wychodzić do nich ze swoją ofertą produktową, zwiększać swoje zaangażowanie na rynku dodatkowych produktów emerytalnych i tym samym wpływać na wyższy standard bezpieczeństwa finansowego polskiego społeczeństwa w okresie starości.

\section{Wykaz źródeł}

Adiev D.M., Sanderson W.C., Scherbov S., The inverse relationship between life expectancy-induced changes in the old-age dependency ratio and the prospective old-age dependency ratio, „Theoretical Population Biology” 2019, No. 125.

Anioła A., Gołaś Z., Zastosowanie wielowymiarowych metod statystycznych w typologii strategii oszczędnościowych gospodarstw domowych w Polsce, „Materiały i Studia. Narodowy Bank Polski" 2012, z. 282.

Behrman J.R., Mitchell O.S., Soo C., Bravo D., Financial Literacy, Schooling, and Wealth Accumulation, „NBER Working Paper” 2010, No. 16452.

Bowen C.F., Financial Knowledge Of Teens And Their Parents, „Financial Counseling and Planning” 2002, No. 13[2].

Bucher-Koenen T., Financial Literacy and Private Old-Age Provision in Germany. Evidence from Save 2008, "Mannheim Research Institute for the Economics of Aging" 2009, https://madoc. bib.uni-mannheim.de/2572/1/meadp_192_09.pdf [dostęp: 15.07.2021].

Buchholtz S., Rutecka-Góra J., The Impact of Framing and Anchoring on Postponing Labour Market Exit - Evidence from Polish NDC+FDC Pension Scheme, "European Research Studies Journal" 2021, Vol. XXIV, Issue 2.

Canova L., Rattazzi A.M.M., Webley P., The hierarchical structure of saving motives, „Journal of Economic Psychology" 2005, No. 26.

Chłoń A., Góra M., Rutkowski M., Shaping Pension Reform in Poland: Security Through Diversity, "SP Discussion Paper" 1999, No. 9923, World Bank, Washington.

Chłon-Domińczak A., Chybalski F., Rutkowski M., The retirement age and the pension system, the labor market and the economy, "mBank-CASE Seminar Proceedings" 2021, No. 16 ?

Chybalski F., Pensionable age vs cross-country diversity of economic activity of the near-elderly, "Journal of Economics, Finance and Administrative Science" 2021, Vol. 26, Issue 51.

Cichowicz E., Rutecka-Góra J., Świadomość Polaków dotyczaca dodatkowego oszczędzania na starość - próba oceny oraz identyfikacji niezbędnych działań, „Problemy Polityki Społecznej. Studia i Dyskusje" 2017, nr 3, https://doi.org/10.33119/PPSSID.2017.38.3 [dostęp: 17.12.2021].

Clark R., d'Ambrosio M., Saving for Retirement: The Role of Financial Education, TIAA-CREF Institute Working Paper 4-070102-A 2002.

Czapiński J., Góra M., Świadomość „emerytalna” Polaków. Raport z badania ilościowego, Publikacje Europejskiego Kongresu Finansowego, Warszawa 2016.

Danieluk B., Zastosowanie regresji logistycznej w badaniach eksperymentalnych, „Psychologia Społeczna" 2010, tom 5, 2-3 (14). 
Finansowy barometr ING, ING, Warszawa 2018, https://www.ing.pl/_fileserver/item/1124121 [dostęp: 15.07.2021].

Finansowy barometr ING, ING, Warszawa 2019, https://www.ing.pl/_ileserver/item/1126898 [dostęp: 15.07.2021].

Fisher P.J., Anong S., Relationship of Saving Motives to Saving Habits, „Journal of Financial Counseling and Planning" 2012, No. 23(1).

Foster L., Young People and Attitudes towards Pension Planning, „Social Policy \& Society” 2017, No. 16(1).

Furnham A., Argyle M., The psychology of money, Routledge, New York 1998.

Furnham A., Cheng H., 2019. Factors influencing adult savings and investments: Findings from a nationally representative sample, „Personality and Individual Preferences” 2019, No. 151.

Gatnar E., Walesiak M., Analiza danych jakościowych i symbolicznych z wykorzystaniem programu R, CH Beck, Warszawa 2011.

Góra M., Palmer E., NDC: The Generic Old-Age Pension Scheme, Progress and Challenges of Nonfinancial Defined Contribution Pension Schemes Volume 1: Addressing Marginalization, Polarization, and the Labor Market, [w:] Holzmann R., Palmer E., Palacios R., Sacchi S. [ed.], World Bank, Washington 2019, doi: 10.1596/978-1-4648-1453-2 [dostęp: 18.12.2021].

Góra M., Rutecka J., Elastyczny system emerytalny a obecne i przyszłe potrzeby jego uczestników, „Ekonomista” 2013, nr 6, http://hdl.handle.net/20.500.12182/932 [dostęp: 10.12.2021]. Góra M., System emerytalny, Polskie Wydawnictwo Ekonomiczne, Warszawa 2003.

Gustman A.L., Steinmeier T.L., Imperfect Knowledge, Retirement and Saving, ,NBER Working Paper” 2001, No. 8406, https://www.nber.org/system/files/working_papers/w8406/w8406.pdf [dostęp: 12.07.2021].

Hadyniak B., Monkiewicz J., Fundusze emerytalne. II filar, Poltext, Warszawa 1999.

Hosmer D.W., Lemeshow S., Applied Logistic Regression, Wiley, New York 2000.

Jaime-Castillo A.M., Public opinion and the reform of the pension systems in Europe: the influence of solidarity principles, „Journal of European Social Policy” 2013, No. 23 (4).

Lee J.M., Sherman D., Savings Goals and Saving Behavior From a Perspective of Maslow's Hierarchy of Needs, „Journal of Financial Counseling and Planning” 2015, No. 26 (2).

Liberda B., Oszczędności gospodarstw domowych - analiza przekrojowa i analiza kohort, [w:] Długoterminowe oszczędzanie. Postawy, strategie i wyzwania, Rutecka-Góra J. [red.], Oficyna Wydawnicza SGH, Warszawa 2016.

Lin C., Hsiao Y.-J., Yeh C.-Y., Financial literacy, financial advisors, and information sources on demand for life insurance, "Pacific-Basin Finance Journal" 2017, No. 43.

Lindner F., Saving does not finance Investment: Accounting as an indispensable guide to economic theory, „IMK Working Paper” 2012, No. 100, http://nbn-resolving.de/urn:nbn:de:101:1-201211143729 [dostęp: 14.07.2021].

Liu Z., Li W., Zhang T., Internet and private insurance participation, "International Journal of Finance \& Economics" 28.08.2020.

Lusardi A., Michaud P.-C., Mitchell O.S., Optimal Financial Knowledge and Wealth Inequality, „Journal of Political Economy" 2017, No. 125[2].

Lusardi A., Mitchell O.S., Financial Literacy and Retirement Preparedness: Evidence and Implications for Financial Education Programs, „Wharton Pension Research Council Working Papers” 200?, No. 568. 
Mączyńska A., Šebo J., Voicu S.D., Carlucci E., Christoff L., Christensen L., Deinema M., Hagen J., Herce J. A., Houdmont A., Gabaut L., Popova Y., Grænge-Hansen L., Meštan M., Naacke G., Nacheva D., Nava C., Joab M., Prache G., Rutecka-Góra J., Url T., Long-Term and Pension Savings. The Real Return. 2020 Edition, Better Finance, Brussels 2020.

Maddala G.S., Ekonometria, PWN, Warszawa 2013.

Marcinkiewicz E., Chybalski F., How to measure and compare pension expenditures in cross-country analyses? Some methodological remarks, „International Journal of Business and Management" 2014, Vol. II(4).

Marcinkiewicz E., Uwarunkowania rozwoju dobrowolnych programów emerytalnych. Perspektywa makro- i mikroekonomiczna, Wydawnictwo Politechniki Łódzkiej, Łódź 2018.

Marcinkiewicz E., Does the retirement saving motive foster higher savings? The evidence from the Polish household survey, „Business and Economic Horizons” 2018, No. 14(1).

Marczak R., Przeglad badań dotyczacych wiedzy i postaw Polaków wobec ubezpieczeń społecznych, ZUS, Kraków, 7 marca 2018, https://www.zus.pl/documents/10182/1507934/02+-+Robert+Marczak.pdf/b751258d-c30a-4c2d-bb16-42cd647fee71 [dostęp: 15.08.2021].

Marczak R., Wiedza Polaków o systemie emerytalnym. Wyniki badań empirycznych, „Polityka Społeczna" 2016, nr 1.

Międzypokoleniowe rozmowy o długach, raport dla Grupy KRUK, TNS Polska, Warszawa 2016.

Mikroekonometria. Modele i metody analizy danych indywidualnych, Gruszczyński M. [red.], Wolters Kluwer, Warszawa 2012.

Mimura Y., Koonce J., Plunkett S.W., Pleskus L., Financial Information Source, Knowledge, and Practices of College Students from Diverse Backgrounds, „Journal of Financial Counseling and Planning" 2015, No. 26[1].

Monticone C., How Much Does Wealth Matter in the Acquisition of Financial Literacy?, „The Journal of Consumer Affairs" 2010, No. 44[2].

Nolan A., Doorley K., Financial Literacy and Preparation for Retirement, IZA DP 2019, No. 1218 ?

OECD/INFE International Survey of Adult Financial Literacy Competencies, OECD, Paris 2016, www. oecd.org/finance/OECD-INFE-International-Survey-of-Adult-Financial-Literacy-Competencies. pdf [dostęp: 15.07.2021].

Otwarte fundusze emerytalne w Polsce. Analiza działalności inwestycyjnej, finansów i decyzji członków, Chybalski F. [red.], CH Beck, Warszawa 2009.

Owczarek D., Niski poziom wiedzy a wyrazista postawa Polaków wobec ubezpieczeń społecznych i Zakładu Ubezpieczeń Społecznych, „Ubezpieczenia Społeczne. Teoria i Praktyka” 201?, Nr 1. Pieńkowska-Kamieniecka S., Rutecka-Góra J., Kowalczyk-Rólczyńska P., Hadryan M., Readability, efficiency and costliness of individual retirement products in Poland, „Equilibrium. Quarterly Journal of Economics and Economic Policy" 2021, No. 16[1], https://doi.org/10.24136/ eq.2021.002 [dostęp: 18.12.2021].

Pieńkowska-Kamieniecka S., Walczak D., Schnabel R., Social insurance knowledge: implications for education, „Ubezpieczenia Społeczne. Teoria i Praktyka” 2021, nr 2.

Prast H.M., van Soest A.H.O., Financial Literacy and Preparation for Retirement, „Intereconomics” 2016, No. 51(3).

Prezentacja wyników „Badania świadomości i wiedzy ekonomicznej Polaków”, NBP 2020. https:// www.nbp.pl/edukacja/badania/wiedza-ekonomiczna-polakow.pdf [dostęp: 12.07.2021]. 
Rajan D., Aziz F., Manab N., Service Quality of Social Insurance Industry and Customer Satisfaction from Malaysian Perspective: Customer Knowledge as a Moderator, „International Academic Research Journal of Business and Technology" 2018, No. 4(1).

Rutecka-Góra J., Bielawska K., Hadryan M., Kowalczyk-Rólczyńska P., Pieńkowska-Kamieniecka S., Zrozumiałość, przejrzystość i efektywność indywidualnych produktów emerytalnych w Polsce, Oficyna Wydawnicza SGH, Warszawa 2020, https://doi.org/10.33119/978-83-8030-3782.2020.202 [dostęp: 18.12.2021].

Stanisz A., Modele regresji logistycznej. Zastosowanie w medycynie, naukach przyrodniczych i społecznych, StatSoft Polska, Kraków 2016.

Świecka B., Grzesiuk A., Korczak D., Wyszkowska-Kaniewska 0., Financial literacy and financial education. Theory and Survey, De Guyter Oldenbourg, Berlin 2019.

Walczak D., Pieńkowska-Kamieniecka S., Gender Differences in Financial Behaviours, "Inzinerine Ekonomika-Engineering Economics" 2018, No. 29(1).

Wärneryd K.-E., The psychology of saving. A study of economic psychology, Edward Elgar Publishing, Cheltenham 1999.

Wiedza i postawy o ubezpieczeniach społecznych. Raport z badań, ZUS, Instytut Spraw Publicznych, Warszawa 2016, https://www.zus.pl/documents/10182/44573/Raport+wiedza+system+eme rytalny/040bd2a1-094a-4d97-9d77-e0bddc19e845 [dostęp: 18.12.2021].

Yuh Y., Hanna S. D., Which households think they save?, „Journal of Consumer Affairs” 2010, No. 44. Yunikawati N.A., Priambodo M.P., Puspasari E.Y., Istiqomah N., Is it Important for Elementary School Students to Learn the Basics of Finance?, "IRCEB International Research Conference on Economics and Business. KnE Social Sciences" 2021.

Zaleśkiewicz T., Psychologia ekonomiczna, PWN, Warszawa 2015.

\section{Impact of social insurance knowledge on supplementary old-age saving in Poland}

In the article we assess the impact of social insurance literacy and pension awareness on propensity to collect supplementary old-age savings. Having used the data from representative quantitative research conducted by Zakład Ubezpieczeń Społecznych in 2016 ( $N=1030)$ and having applied logistic regression model with $\chi^{2}$ test of independence, we found that the higher the social insurance knowledge is, the higher the aptitude for additional pension saving is. Moreover, the social insurance literacy level is affected by the sources of information about the social security system. The highest knowledge was observed among people that are provided with information by family and friends, representatives of Social Insurance Institution (ZUS) and social security experts. The obtained results are important for financial institutions that provide individuals with long-term investment and savings products, in particular for life insurers that have a broad offer of retirement products and employ experts who can educate individual savers.

Keywords: social insurance knowledge, pension awareness, old-age saving, supplementary pension system, sources of knowledge. 
DR SYLWIA PIEŃKOWSKA-KAMIENIECKA - Katedra Finansów, Wydział Nauk Ekonomicznych Uniwersytetu Warmińsko-Mazurskiego w Olsztynie

ORCID: 0000-0002-5818-2658

e-mail: sylwia.pienkowska@uwm.edu.pl

DR HAB. PATRYCJA KOWALCZYK-RÓLCZYŃSKA - profesor Uniwersytetu Ekonomicznego we Wrocławiu, Katedra Ubezpieczeń, Wydział Ekonomii i Finansów UEW

ORCID: 0000-0002-7952-7678

e-mail: patrycja.kowalczyk@ue.wroc.pl

DR HAB. JOANNA RUTECKA-GÓRA - profesor Szkoły Głównej Handlowej, Zakład Demografii Instytutu Statystyki i Demografii w Kolegium Analiz Ekonomicznych SGH

ORCID: 0000-0002-2509-8599

e-mail:jrutec@sgh.waw.pl 